Article

\title{
Tourism in the Era of Covid-19 and Its Impact on the Environment
}

\author{
Rafał Nagaj ${ }^{1, *(1)}$ and Brigita Žuromskaite ${ }^{2}$ (D) \\ 1 Institute of Economics and Finance, University of Szczecin, 71-101 Szczecin, Poland \\ 2 Faculty of Public Governance and Business, Mykolas Romeris University, LT-08303 Vilnius, Lithuania; \\ brigitaz@mruni.eu \\ * Correspondence: rafal.nagaj@usz.edu.pl; Tel.: +48-502160109
}

check for

updates

Citation: Nagaj, R.; Žuromskaitè, B. Tourism in the Era of Covid-19 and Its Impact on the Environment. Energies 2021, 14, 2000. https://doi.org/ $10.3390 /$ en 14072000

Academic Editor: George Xydis

Received: 27 February 2021

Accepted: 1 April 2021

Published: 5 April 2021

Publisher's Note: MDPI stays neutral with regard to jurisdictional claims in published maps and institutional affiliations.

Copyright: (c) 2021 by the authors. Licensee MDPI, Basel, Switzerland. This article is an open access article distributed under the terms and conditions of the Creative Commons Attribution (CC BY) license (https:// creativecommons.org/licenses/by/ $4.0 /)$.

\begin{abstract}
The Covid-19 pandemic has affected all areas of socio-economic life around the world. Its impact concerns not only the health system and the health of the population, but also the economy. Tourism is one of the sectors hardest hit by the restrictions imposed by governments in the wake of the pandemic. The pandemic has resulted in restrictions and limitations on movement and travel, covering both domestic and international tourism, which raises the question of have these restrictions imposed on tourist activities also caused an environmental impact? The aim of this article is to examine what impact the COVID-19 pandemic has had on the environmental issues within the tourism sector in the Central and Eastern European (CEE) region. The research task is to investigate whether this impact has changed in the pandemic era compared to previous years, and whether it has been positive or negative. The research method is multiple regression analysis. The results of the study indicated that the COVID-19 pandemic caused a decrease in greenhouse gas emissions from tourism in all CEE countries. Such decreases are both relative to 2019 and the estimated level of emissions that would be achieved if the countries surveyed achieved economic growth in 2020 consistent with the European Commission's projections for that year. The scale of the impact varies from country to country, while the relationship between tourism development and pollution levels is positive.
\end{abstract}

Keywords: Covid-19; tourism; economy; environment

\section{Introduction}

The major problem faced by the global economy in 2020 was the COVID-19 pandemic. Its impact has been seen not only in the sphere of healthcare [1], but it has also affected the economic growth, the business model of companies [2,3], the need for government aid programs, as well as the condition of public finances [4]. As Çetin and Kara [5] point out, while from the perspective of public finances, pandemic diseases can only cause short-term fiscal shocks, from the point of view of economic growth, the impact will be long-term. Moreover, as the literature indicates, coronavirus has caused disruption to the energy sector and the prospects for rapid clean energy transitions [6], and thus contributed to energy poverty [7] and the state of the environment [8]. Thus, the COVID-19 pandemic has left its mark on many areas of socio-economic life.

Pandemics and other global crises have a devastating impact on tourism, especially in the economic area, as the COVID-19 disease has just confirmed [9]. In particular, COVID-19 caused unprecedented damage to the tourism sector [10]. Tourism is one of the sectors that has been hardest hit by the strictures imposed by governments in the wake of the pandemic. The pandemic resulted in restrictions on movement and travel. The restrictions have affected both domestic and international tourism (outbound and inbound) and, according to politicians, the hospitality industry is the one where they are likely to remain in place the longest. 
However, the pandemic has not caused any change in the priorities of the European Union, but only the addition of another one, i.e., the fight against this virus and its consequences, so that the effects on the economy are as small as possible. The basic, if not primary, long-term EU priority is still its climate policy [11]. Although COVID-19 has significantly hindered the development of renewable energy and low carbon economy [12], nothing has changed in terms of priorities. The global goal of green growth and sustainable development, with the care for the environment being its essential element, is timeless [13]. Therefore, the analysis of the development of the tourism sector should encompass its impact on the environment as well. The literature indicates that this impact can be positive as well as negative. Russo et al. [14] believe this impact to be negative, while Gössling et al. [15] claim that, contrary to popular opinion, tourism can affect the environment in a similar way as other economic activities, although of course it depends on the tourist destination. On the other hand, the results of Tian et al. [16] research indicate that in the long term the growth of the tourism sector reduces the emission of pollutants. So what impact did the restrictions on tourism activities during the COVID-19 pandemic have on the environment?

The purpose of this paper is to examine what effect the COVID-19 pandemic has had on the environmental impact of the tourism sector in the Central and Eastern European (CEE) region. The literature on the topic of tourism-emission linkages is rather scarce. As pointed out by Russo et al. [14] (p. 1) there is few available data on the emission of atmospheric pollutants from tourism activities, and the awareness of this issue can be regarded as a critical knowledge gap. Most of the research on this topic so far has focused on how to measure emissions, how to collect these data for tourism $[14,17]$ or how to calculate total emissions from tourism [18]. Also, there are studies on the relationship between environment and tourism indicating that air quality determines the demand for tourism [19]. In another research project covering the period of 1995-2011, Dogan and Aslan [20] indicated a long-term relationship between carbon emissions, real income, energy consumption and tourism. There are also few studies available on factors influencing the tourism industry's carbon emissions [21,22]. However, the literature is not clear on the environmental impact of tourism. Katircioglu et al., [23] believe that international tourism, the growth of tourist transport and the number of incoming tourists determine the level of carbon emissions, and that this relationship is positive. However, not every author is so critical. Dogan and Aslan [20] indicate that real income and the tourism sector mitigate $\mathrm{CO}_{2}$ emissions, while Tian et al., [16] claim that it is not the tourism industry that is to blame for environmental pollution but the energy sector, while the development of tourism can be an engine for reducing energy consumption and $\mathrm{CO}_{2}$ emissions in the long run.

To date, there is little research on the environmental impact of tourism and the literature is scarce and inconclusive on this issue. Furthermore, tourism and its impact on the environment is often seen only by considering the impact of transport, forgetting that the accommodation sector and related services also have an environmental related impact, for example through the energy consumed (heating, air conditioning, lighting etc.). Hence, the assessment of the footprint that the Covid-19 pandemic has had on the impact of the accommodation sector on greenhouse gas (GHG) emissions in CEE countries seems to be a research area that has been unexplored and worth investigating so far. The contribution of this paper to the literature is threefold. Firstly, the existing knowledge about the impact of tourism on the environment is poor and does not provide a clear answer about the trends in the impact of tourism growth on the natural environment. Secondly, there is no research on how the impact of tourism-related accommodation sector on GHG emissions has changed due to COVID-19. Researchers have focused on such issues as the impact of the COVID-19 pandemic on tourism demand, the economy in general, the public finances, the natural environment in the country as well as on the restrictions imposed on accommodation industry, or how to manage tourism infrastructure and minimize economic losses in the post-pandemic period. However, the impact of the tourism sector on GHG emissions has not been the subject of scientific studies yet. Thirdly, there is a deficit of research on the 
relationship between the environment and tourism industry in the CEE region. So far, all available studies on environmental issues have focused on climate change in Western European cities or the Asian region, while the CEE region has been neglected.

The purpose of the present study and the research gap determines the structure of the paper which is as follows: Section 2 is devoted to a review of literature discussing the relationship of tourism with COVID-19 and with the natural environment. Section 3 presents the methodology, while Section 4 outlines the results. The paper concludes with Section 5 containing the discussion and the main conclusions from the analysis and research.

\section{Literature Review}

\subsection{COVID-19 and the Tourism Sector}

2.1.1. Economic Impact of the Pandemic on the Tourism Sector

In 2020 COVID-19 resulted in losses for almost the entire global economy and especially for the tourism sector [24-27]. The stringent restrictions applied to combat the COVID-19 pandemic brought the global tourism industry to a complete halt [28]. The scale of the economic impact of COVID-19 is incomparable to previous crises [9]. The new and stricter measures introduced by governments, further aggravated the crisis in the tourism sector. Among the measures to counteract pandemics, the most noticeable were restrictions on the mobility of global travelers as well as social distancing [29]. As indicated by the WTO, in March 2020 when the first lockdown was introduced, tourist traffic decreased by $56 \%$, to fall further to $98 \%$ in May. In the entire 2020, overall international arrivals were down by $74 \%$ [30] (p. 1). The collapse in international travel represents a worldwide loss of $\$ 1.3$ trillion in export earnings-more than 11 times the losses recorded during the 2009 global economic crisis. [30] (p. 3). This decline in international tourism has translated into economic losses in tourism measured by a global product value of US $\$ 2$ trillion, i.e., more than 2\% of global GDP [30] (p. 3). The economic impact of the COVID-19 disease was particularly painful for small and medium-sized companies, which had to halt business operations altogether and some of them laid off employees as a result [31]. According to WTO data, this crisis has also threatened the existence of 100-120 million direct tourism jobs, a large share of which are held by women and youth [30] (p. 3). What a shock COVID-19 was for the tourism sector in Central and Eastern Europe, which is the subject of this study, is perfectly illustrated by the basic data on the growth of tourism-related accommodation industry in this region and on the domestic revenue from international tourism, as shown in Table 1.

Table 1. Average annual growth of tourism activity in 2008-September 2020 (\% change over same period of previous year) (Source: [32-34]) (Annex 11-12).

\begin{tabular}{ccccccccc}
\hline \multirow{2}{*}{ Country } & \multicolumn{2}{c}{ Arrivals at Tourist Accommodation Establishments } & \multicolumn{3}{c}{ International Tourism Receipts } \\
& $\mathbf{2 0 0 8 - 2 0 1 2}$ & $\mathbf{2 0 1 3 - 2 0 1 8}$ & $\mathbf{2 0 1 9}$ & $\mathbf{2 0 2 0}$ & $\mathbf{2 0 1 2 / 2 0 0 8}$ & $\mathbf{2 0 1 8 / 2 0 1 2}$ & $\mathbf{2 0 1 9}$ & $\mathbf{2 0 2 0}$ \\
\hline Bulgaria & 2.5 & 6.0 & 5.0 & -62.5 & -3.8 & 4.2 & -4.6 & -64.7 \\
Czech & 4.1 & 5.9 & 3.5 & -67.5 & -1.1 & 0.0 & -1.9 & -36.4 \\
Republic & & 4.0 & 5.5 & -62.7 & 0.9 & 6.4 & -2.1 & -62.5 \\
Estonia & 4.5 & 9.3 & 1.6 & -53.8 & -1.7 & 6.0 & -4.0 & -46.8 \\
Latvia & 1.4 & 8.3 & 11.5 & -67.9 & 4.0 & 2.2 & -0.8 & -60.7 \\
Lithuania & 8.9 & 6.9 & 2.6 & -15.1 & -3.9 & 5.4 & 5.5 & -42.7 \\
Hungary & 3.6 & 7.0 & 5.2 & -16.1 & -1.4 & 3.9 & -1.1 & -39.2 \\
Poland & 3.7 & 9.0 & 3.6 & -80.2 & -7.4 & 15.1 & 5.2 & -57.9 \\
Romania & 1.8 & 10.2 & 6.5 & -70.1 & -0.4 & 3.2 & -3.5 & -55.5 \\
Slovenia & 2.6 & 6.6 & 14.2 & -57.1 & -2.9 & 5.7 & 0.1 & -59.0 \\
Slovakia & -1.9 & & & & & & &
\end{tabular}

The COVID-19 pandemic revealed the weaknesses of the tourism sector and its incapacity to handle an emergency crisis of this magnitude. The tourism sector was completely unprepared for such a challenge [35] and the sheer scale of the economic impact exposed 
the lack of knowledge and limited capability of the tourism industry to foresee and manage this type of risk [36].

All the restrictions have had a direct impact on the volume of travel, which affected the entire tourism infrastructure. Curtailment of travel has had a negative effect on the operations of airlines which have reduced both domestic and international services [26]. It has also impaired the operations of rail and bus service providers [26]. This has resulted in a decrease in fuel demand worldwide, which in turn has reduced energy consumption and oil demand [37]. However, the tourism sector has not completely ceased to function, just as during previous crises, e.g., those caused by terrorism, when tourism recovered soon after and began to generate revenue again [38]. As Canh and Thanh [39] note, during certain periods of time the pandemic even had a positive impact on domestic tourism which depends generally on internal factors that tend to be insensitive to shocks in international markets.

After the collapse of international tourism in 2020 brought upon by the COVID-19 pandemic, the growth prospects for the sector are mixed and still largely dependent on the development of the health crisis. Tourism development forecasts and international tourist arrivals in the world after the COVID-19 pandemic are shown in Figure 1.

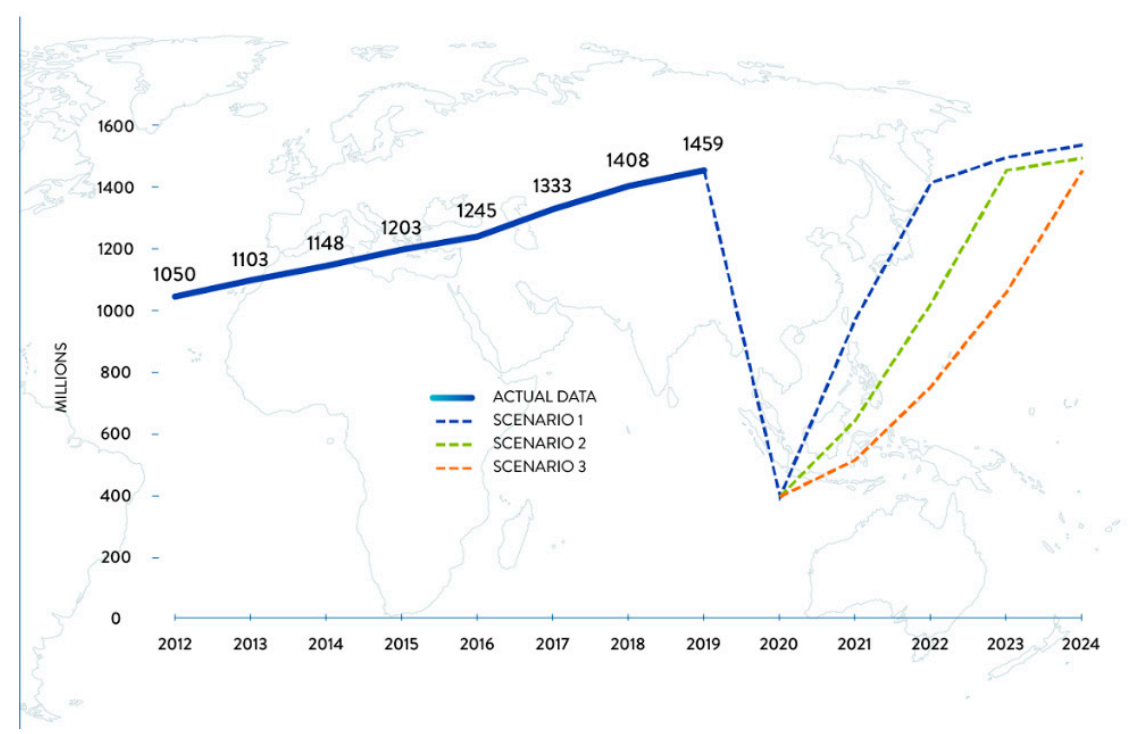

Figure 1. Forecasts of international tourist arrivals in the world after the COVID-19 pandemic. Source: [30] (p. 13).

The UNWTO's most optimistic scenario (Figure 1) shows a rebound only in the second half of 2021, and this is provided that the pandemic is partially contained and travel restrictions are lifted.

\subsubsection{Security Measures and the Tourism Sector}

The worsening epidemiological situation has necessitated stringent forms of pandemic control. In 2020, restrictions were introduced that had not been seen on such a scale for a long time and that would restrict tourists' freedom to travel so much. The development of the COVID-19 pandemic made it impossible to do business for the tourism sector around the world, as each loosening resulted in new waves of disease and the introduction of new sanitary restrictions by governments. The result was an increase in travel insecurity for tourists and the economy due to constant changes in laws and existing restrictions on businesses (including border closures) in the face of a constantly changing epidemiological situation.

The primary security measure and restriction applied by governments to the accommodation industry and the tourism sector as a whole was quarantine and mobility restrictions. However, countries applied many other strictures such as: various forms of 
non-pharmaceutical interventions (NPI), including lockdown, social distancing, closure of schools/universities and non-essential businesses/workplaces, cancelling or postponing events (i.e., major conferences and tradeshows, concerts and festivals, political debates and elections, sports seasons and etc.), and bans on gatherings of people over certain numbers ([29], p. 2). The most economically severe restrictions imposed on the tourism sector were curtailment of travel, closure of local attractions and tourism facilities, rescinding of consumer protection rights in accommodation and tourism, return to the mothership, confinement to place of residence and penalties for non-compliance, restrictions on rights to visit friends and family, confinement in tourism locations, abuse of minorities, boycotting of their businesses ([26], pp. 2400-2402). The literature unanimously reports that border closures and travel bans have been the most severe barriers to tourism development [40]. Many countries have enacted travel bans, either by closing borders completely or by imposing quarantine periods for travelers [29] and by requiring a negative certified test $(24,48$, or $72 \mathrm{~h}$ ). As Baum and Hai [26] point out, the uniqueness of this situation is confirmed by the fact that even border control in the Schengen area in Europe has been restored. Outside Europe the situation was not much different. Many countries such as Australia, China and New Zealand, closed their borders completely to non-nationals and non-residents. Vietnam withdrew Visa on Arrival schemes while others, for example Singapore, removed the right to transit through airports [26] (p. 2400). This shows that the restrictions affecting the tourism sector has a global dimension. In addition to the above restrictions, many other security measures of epidemiological nature were introduced in the tourism sector, such as: disinfection of hotel rooms and other tourist facilities, mandatory hand disinfection, consumer temperature testing, restrictions on the number of people allowed to stay in one room.

As shown by the experience of other crises in the past (e.g., caused by terrorist attacks or natural disasters), tourists can react differently to security measures in tourism infrastructure [41], and the tourism sector is able to recover and resume its activities in the new, changed reality quite quickly, which results, among others, from the high level of competitiveness of companies operating in this market [42]. Therefore, according to Assaf and Scuderi [43], despite the difficult situation in the tourism sector, it is necessary to start working on strategies for its recovery now. Altuntas and Gok [44] emphasize that once the pandemic is over, the main challenges that businesses in the tourism sector will have to face will include: the implementation of new health safety standards, possible reduced occupancy rates for hotels and restaurants, the introduction of new technologies to reduce personal contacts among customers and staff (e.g., check-in kiosks and payments via bank transfer), or room service at hotels replacing buffets or breakfast bars ([43], p. 732). As Assaf and Scuderi add: "automation technologies, robots and artificial intelligence may help facilities to decrease their fixed costs, improve liquidity and resilience and help to maintain social distance" ([43], p. 732).

\subsection{Tourism and the Environment}

The COVID-19 pandemic has caused major economic impacts on the global economy, including its tourist sector, as well as those related to restrictions and security measures. However, it has not changed the long-term priorities of the European Commission concerning the socio-economic development of the European Union. The EC long-term priorities still refer to the job market, innovation and climate policies. These goals have now been somewhat subdued by the current short-term overarching goal of defeating the pandemic and unblocking economies. However, the primary, if not the most important long-term priority is still the climate policy (European Energy Network, 2019). Data from the U.S. National Aeronautics and Space Administration (NASA) and the European Space Agency (ESA) have indicated that pollution due to the overall economic activity reduction in some COVID-19 epicenters such as Wuhan, Italy, Spain, USA, etc., has decreased by up to $30 \%$ [37]. Tourism should not be considered as an isolated economic sector when it comes to environmental performance. Gössling et al. [15] indicate that, like other eco- 
nomic activities, tourism can have a negative effect on the environment as well as lead the development of eco-effectiveness. However, as they point out, this relationship is often highly variable and depends on the country and the nature of its local tourism industry. They conclude that when the impact is eco-effective, it can have a positive impact on the economic performance of tourism. As Katircioglu et al., [23] observe, the negative environmental impact is not caused by every kind of tourism activity, but only by international tourism. According to them, the increase in the number of tourist arrivals boosts energy consumption and thus carbon dioxide emissions. At the same time, the study on the period between 1995-2011 conducted by Dogan and Aslan [20] indicate that there is a long-lasting relationship between carbon emissions, real income, energy consumption and tourism. The amount of energy consumed has a positive effect on emissions, while real income and the tourism sector have a negative effect by moderating $\mathrm{CO}_{2}$ emissions. Meanwhile Leitão and Lorente [45] indicate that tourism arrivals are negatively correlated with carbon dioxide emissions. A broader conclusion regarding the determinants of carbon emissions in tourism was presented by Tang et al. [21]. They indicate that the increase in the measures of economic activity in tourism, i.e., the volume of tourist traffic and tourist production, as well as the energy structure affect the increase in carbon dioxide emissions. What inhibits this negative impact on the environment is the decrease in energy intensity. Similarly, Robaina-Alves et al. [22] emphasize the role of carbon intensity and energy intensity effects. As Sun [46] points out, technological progress is the main factor influencing the production of carbon dioxide in tourism. If tourism grows more slowly and the share of tourism in GDP declines, then there is a slow technological improvement in tourism-specific industries.

Within the tourism infrastructure, transport is considered to be the most environmentally polluting $[47,48]$. It is responsible for about $75 \%$ of $\mathrm{CO}_{2}$ emissions in tourism [49]. However, the literature indicates that accommodation facilities (the accommodation sector), which are the focus of this paper, are also a source of pollutant emissions [49-51]. The ecological impact of the accommodation sector, or accommodation-related activities more broadly, is likely to go unnoticed due to difficulties with the carbon reporting mechanism of this economic activity [52,53]. Tourism accommodation is responsible for $21 \%$ of the $\mathrm{CO}_{2}$ emissions delivered by the entire tourism industry, and the environmental impact is through greenhouse gas emissions, wastewater discharge and other [49-51]. As indicated in the literature [54,55], tourism accommodation contributes significant amounts of energy consumption (mainly through the use of air conditioning, heating and lighting) and $\mathrm{CO}_{2}$. Thus, in Taiwan for example, the average $\mathrm{CO}_{2}$ emission in the accommodation base per person per night is, depending on the standard of the accommodation facility, $6.3-28.9 \mathrm{~kg}$ ([50], p. 13). The literature indicates that the level of GHG emitted by accommodation facilities and tourists arriving at tourist accommodation establishments, varies depending on the standard of the facility or hotel. It is also highlighted that the environmental impact of the accommodation sector can vary by country $[50,56,57]$. This is due to the level of investment (improving productivity and eco-efficiency) implemented in tourism in the respective countries. Thus, for example, according to the Cornell Hotel Sustainability Benchmarking Index in 2018, Switzerland's carbon intensity was $20.4 \mathrm{~kg}$ $\mathrm{CO}_{2}$ per square metre, while South Africa's was $209.8 \mathrm{~kg}$ - [58]. For this reason, many accommodation facilities join environmental programmes to reduce their negative impact on the environment. The importance of environmental orientation in tourism, including accommodation and international tourism activities, can be seen from the fact that tourism is expected to contribute about $7.5 \%$ of global $\mathrm{CO}_{2}$ emissions in 2035 [59]. However, the fact that the development of this sector of the economy may affect the reduction of emissions is confirmed by the fact that the goal of the global hotel industry is to reduce GHG emissions per room per year by $66 \%$ by 2030 and by $90 \%$ by 2050 compared to 2010 levels [60]. To sum up this relationship, the more services are provided, the more energy is consumed and thus greenhouse gases are emitted by the accommodation establishments. On the other hand, the faster the tourism sector develops, the more innovations are implemented (including 
eco-friendly innovations), the less energy is consumed, which results in a decrease in greenhouse gas emissions by the accommodation facilities. Hence, the environmental related impacts of COVID-19 from this economic activity are not so obvious.

So far, few authors have dealt with the impact of tourism on $\mathrm{CO}_{2}$ emissions. What is more, their findings are inconclusive. The main studies on this topic were conducted by Lee and Brahmasrene [61], Katircioglu [62] and Paramati, Shahbaz and Alam [63]. While analyzing the environmental Kuznets curve hypothesis, Katircioglu [62] indicated that tourism had a negative impact on carbon emissions in both long and short perspective. Similarly, Lee and Brahmasrene [61] who investigated the role of tourism on economic growth and $\mathrm{CO}_{2}$ emissions in the European Union in 1988-2009 and found that tourism had no negative impact on the environment and was significantly negatively correlated with $\mathrm{CO}_{2}$ emissions. However, slightly different conclusions were provided by Paramati, et al. [64] who proved that the impact of tourism on $\mathrm{CO}_{2}$ emissions decreases much faster in the developed economies than in the developing ones. An opposite finding has been provided by a study conducted in the EU that covered the period of 1991-2013 [63], according to which tourism reduces $\mathrm{CO}_{2}$ emissions in the western part of the EU and contributes to them in the eastern part of the EU. It has been indicated that the effect of tourism on $\mathrm{CO}_{2}$ emissions largely depends on the adaptation of sustainable tourism policies and efficient management [63] (p. 1). Similar conclusions have been provided by Tian et al., [16] who analyzed G20 economies from 1995 to 2015. They believe that the tourism industry is not to blame for environmental pollution and is wrongly accused of it. Moreover, the growth tourism sector can be an engine to reduce $\mathrm{CO}_{2}$ emissions, because in the long perspective a $1 \%$ increase in tourism growth reduces pollutant emissions by $0.05 \%$ [16] (p. 53).

The COVID-19 pandemic has undoubtedly caused an impact on the development of the tourism sector and energy consumption [65]. It was no surprise that the prolonged quarantine, the closure of economies and country borders, created an unprecedented opportunity to answer the question: what impact does tourism have on the environment during a pandemic? However, research to date related to the impact of COVID-19 pandemic has been limited to environmental chemical changes in the world's most polluted regions, effects on water quality or changes in minimum temperature levels in Arctic regions. In the first research area, studies have focused on cities where very high levels of air pollution are recorded, e.g., from India, China, Brazil [66-68]. Changes in the concentrations of chemical compounds in the air of the studied cities caused by restrictions in transport traffic, mobility and a decrease in the number of journeys made were studied by literature [69]. Similar studies, although related to $\mathrm{NO}_{2}$, were also done for Spain, France and Italy, indicating a decrease in the concentration of this chemical in the air [70,71].

From the latter research area related to COVID-19, researchers chose such topics as waterways transport traffic in Venice [72] finding that the COVID-19 pandemic significantly contributed to the reduction of waterways transport infrastructure. That was particularly painful to the cruise industry, where passengers were trapped on cruise ships for many weeks due to infection [73]. However, the decrease in waterways traffic has had a significant impact on water quality. Braga et al. [74] studying the lagoon of Venice by means of satellite imagery compared what it looked like in 2019 and 2020. They found that the COVID19 pandemic resulted in improved water quality in the Venice canals and the lagoon. Some authors have also examined the effects of COVID-19 on temperature levels. Studies conducted in New York have shown that the mean temperature and minimum temperature in that city have been largely associated with COVID-19 pandemic [75,76].

In summary, while the literature has not yet examined the direct impact of COVID-19 on the tourism sector, particularly the accommodation industry, and its effect on GHG emissions, it has showed indisputably that tourism, like other industries, has an impact on the environment (although there is no scientific consensus on the direction of this impact). The literature has also indicated that the global pandemic has caused all branches of the tourism sector to suffer significant economic losses, contributing in many cases to the 
real risk of the disruption of business operation in the industry. However, as noted by Lokhandwala and Gautam [77], it was as a blessing for nature and environment on an economy-wide scale.

\section{Materials and Methods}

The purpose of this paper is to examine what impact tourism has had on the environment in the era of the COVID-19 pandemic. The authors intend to examine whether this impact has changed from previous years, what changes have occurred relative to 2019 and 2020 projections (given the economic growth projected for that year), and to determine whether this pandemic impact has been positive or negative. The research method used in this analysis is multivariate regression, which will allow the identification of factors influencing GHG levels (of course, it was previously established that the prerequisites for its application were satisfied). And all statistical calculations, including those for multiple regression analysis, were performed using Statistica 13.3 software (TIBCO Software, Dublin, Ireland company, city, state abbrev if USA, country). As regards the tourism sector, the analysis focuses on tourist accommodation establishments and their business operations, rather than on the tourism industry as a whole. Therefore, whenever the term tourism sector is used in the empirical analysis, the business operation in the area of Accommodation and Food Service Activities are referred to. As far as the environment is concerned, the area of analysis covers the emission of greenhouse gases (GHG) which, according to the methodology used by Eurostat, includes $\mathrm{CO}_{2}, \mathrm{~N}_{2} \mathrm{O}$ in $\mathrm{CO}_{2}$ equivalent, $\mathrm{CH}_{4}$ in $\mathrm{CO}_{2}$ equivalent, $\mathrm{HFC}$ in $\mathrm{CO}_{2}$ equivalent, $\mathrm{PFC}$ in $\mathrm{CO}_{2}$ equivalent, $\mathrm{SF} 6$ in $\mathrm{CO}_{2}$ equivalent, $\mathrm{NF}_{3}$ in $\mathrm{CO}_{2}$ equivalent. This particular methodology for measuring GHG emissions has been adopted because the countries analyzed belong to the European Union and report data based on the terminology and methodology used by the European Commission.

In this paper the analysis covers the Central and Eastern European region, which was less affected by the first wave of the pandemic than the Western European countries, while the infection rates were among the highest in the world during the second wave of the pandemic. The study looks at 10 countries in this region that belong to the European Union: Bulgaria, the Czech Republic, Estonia, Latvia, Lithuania, Hungary, Poland, Romania, Slovenia and Slovakia. The research period is 2008-September 2020 (for which data is available). Data for the calculations are sourced from: Eurostat, the United Nations World Tourism Organization (UNWTO) and the Organization for Economic Cooperation and Development (OECD).

To start with, the relationship between GHG emissions and the level of development of the tourism sector from 2008 to 2019 was examined. This was necessary for forecasting how the GHG emissions would evolve in the tourism sector in 2020, i.e., when tourism sector was shaped by the pandemic conditions. The literature indicates that the main factors affecting the pollution levels are the level of economic development, the intensity of emissions, the amount and type of energy carriers consumed and, finally, the size of population or tourism arrivals [45]. In the first group of factors, GDP growth [20,78] and the development of tourism activities [21] are identified. Pointing to the environmental impact of GDP (which in the literature is usually based on the theory of the environmental Kuznets curve), it is stressed that this relationship is strong [79], but it is also pointed out that it occurs mainly in the analysis of a single country and not necessarily in the analysis conducted for a group of countries or internationally [78]. Meanwhile, referring to the factors representing the level of economic activity in tourism, the literature points out that in industries specific to tourism, slower growth or crisis results in a lack of technological improvement, which in turn may be reflected in higher carbon production by tourism [46]. The literature also indicates a relation between tourism arrivals [45] and turnovers generated by tourism sector [15] and the level of environmental performance, and the intensity of emissions [22]. For the reasons outlined above, when determining the relationship between total GHG emissions and the situation in the tourism sector, the independent variables taken into account were those related to the growth rate of 
the overall economy, the eco-effectiveness of production in the tourism sector (measured by the amount of emissions per one unit of production) and the economic situation in the sector under study. Thus, the following independent variables were adopted for the regression analysis:

$X_{1}$-real GDP growth rate -\% change over same period of previous year (Eurostat data),

$X_{2}$-Air emission intensity for greenhouse gases per unit of output in the tourism sector (Eurostat data),

$X_{3}$-number of arrivals at tourist accommodation establishments (Eurostat data; UNWTO data),

$\mathrm{X}_{4}$ - average level of employed persons in tourism sector (accommodation and food service activities) (Eurostat data),

$X_{5}$-number of nights spent at tourist accommodation establishments by residents/nonresidents (Eurostat data),

$X_{6}$-turnover value in tourism sector (Eurostat data),

$X_{7}$-international tourism receipts (OECD data; UNWTO data),

$\mathrm{X}_{8}$-international tourism expenditure -\% change over same period of previous year (OECD data; UNWTO data).

The period on the basis of which the relationship was determined was 2008-2019 (only for this period complete data on the dependent variable are available). On the basis of the results of this analysis, for each of the $m$ countries analysed $(m=1, \ldots, 10)$, the independent variables determining the level of greenhouse gas emissions in tourism were selected and a multiple regression equation was constructed:

$$
Y_{m}=a+b_{1} \cdot X_{1}+b_{2} \cdot X_{2}+\cdots+b_{n} \cdot X_{n}
$$

where $Y_{m}$-level of greenhouse gas emissions in tonnes (dependent variable) for each of the $m$ countries analysed $(m=1, \ldots, 10) ; a, b_{1}, b_{2}, \ldots, b_{n}$-parameters and coefficients of the regression function $(n=1, \ldots, 8)$ and $X_{1}, X_{2}, \ldots X_{n}$-independent variables affecting the dependent variable during the period under consideration $(n=1, \ldots, 8)$.

Additionally, the regression analysis was preceded by the analysis of correlation between independent variables for each of the studied countries. On this basis, a strong correlation was found for two independent variables, which resulted in excluding the variables $X_{5}$ and $X_{8}$ from the regression analysis. Finally, six independent variables $\left(X_{1}\right.$, $\left.X_{2}, X_{3}, X_{4}, X_{6}, X_{7}\right)$ were used in the regression analysis.

With the help of the regression analysis covering the years 2008-2019 discussed above, the authors determined which variables influenced the level of GHG emissions from the tourism sector in each of the CEE countries. The results of these analyses and the data about the situation in the tourism sector in 2020 (the situation in 2020 had been determined basing on data from January-September 2020, i.e., the period for which the data were available) were then used to estimate the actual values of pollutant emissions in each of the examined countries in 2020. These data on emissions in 2020 (i.e., the period of the pandemic) were then compared with the level of GHGs emitted by the tourism sector in 2019 , i.e., the period when pandemic had not started yet. In this way, it was possible to estimate what environmental change occurred relative to 2019 and to identify the impact of this pandemic on the environment, and more specifically, on changes in the level of GHGs emitted by the tourism sector.

However, it is important to note that the COVID-19 pandemic was not expected, and the forecasts for 2020 were favorable [80]. Therefore, in order to determine the potential impact of the COVID-19 pandemic on the environment via tourism (i.e., taking into account potential economic growth in CEE countries), it was necessary to compare these estimated 2020 emission data with a hypothetical situation in tourism as if there had been no pandemic and the economy had grown rather than contracted. In this way, the authors determined the deviation of the actual values from the projected ones in terms of the level of GHGs emitted by tourism. For this reason, the estimated actual emission data in 2020 (i.e., in the 
pandemic) was compared with the projected level of pollution, i.e., the pollution that would have been emitted by tourism if there had been economic growth instead of recession [80].

Since there is a strong positive correlation (statistically significant correlation) between economic growth (measured by the change in GDP) and the level of tourism sector development (measured by the turnover value of businesses of enterprises in the tourism sector) (see Table 2), therefore the knowledge about this correlation will be used to calculate the potential impact of COVID-19 on the level of GHGs emitted by tourism in the CEE countries. Table 2 shows the results of this correlation.

Table 2. European Commission Autumn 2019 forecast of economic growth in 2020 and the results of the correlation between turnover value in tourism sector and gross domestic product at market prices in 2008-2019 in Central and Eastern European countries.

\begin{tabular}{ccc}
\hline Country & GDP Growth Forecast for 2020 (in \%) & Correlation Index \\
\hline Bulgaria & 3.0 & 0.98 \\
Czech Republic & 2.2 & 0.91 \\
Estonia & 2.1 & 0.97 \\
Latvia & 2.6 & 0.96 \\
Lithuania & 2.4 & 0.98 \\
Hungary & 2.8 & 0.96 \\
Poland & 3.3 & 0.92 \\
Romania & 3.6 & 0.98 \\
Slovenia & 2.7 & 0.96 \\
Slovakia & 2.6 & 0.94 \\
\hline
\end{tabular}

Source: Eurostat data; own calculations.

This was be done in the following way: with the use of the regression analysis, the coefficients of the GDP impact on turnover in the tourism sector in each of the countries under study was calculated, then the potential turnover value in the tourism sector for the projected economic growth in 2020 [80] was estimated. In the next step, the potential level of GHG emissions in such an economic situation was estimated. Having obtained those data, the authors compared them with the actual level of GHG emissions at the time of the pandemic, i.e., the deviation of the actual values from the projected ones was established.

\section{Results}

First, a regression analysis was conducted for each of the $10 \mathrm{CEE}$ countries to determine which dependent variables influenced GHG emissions in the tourism sector during the pre-pandemic study period, i.e., 2008-2019. The results of this analysis are presented in Table 3.

Table 3. Results of regression analysis for CEE countries calculated for the period 2008-2019 (at 0.05 significance level).

\begin{tabular}{|c|c|c|c|c|}
\hline Specification & Coefficients $b$ * & Standard Error & t-Statistic & $p$ Value \\
\hline \multicolumn{5}{|c|}{ Bulgaria } \\
\hline$n=12$ & \multicolumn{4}{|c|}{$\begin{array}{l}\text { Regression statistics: } \mathrm{R}=0.9938 ; \mathrm{R}^{2}=0.9876 \text {; Adjusted } \mathrm{R}^{2}=0.9849 ; \\
\mathrm{F}(2,9)=359.8410 ; p<0.0000 ; \text { Standard error of estimate: } 1852.8158\end{array}$} \\
\hline Constant & $-63,091.3413$ & 5533.1626 & -11.4024 & 0.0000 \\
\hline Variable $X_{2}$ & 1769.3438 & 67.6587 & 26.1510 & 0.0000 \\
\hline Variable $\mathrm{X}_{6}$ & 33.8644 & 1.5907 & 21.2888 & 0.0000 \\
\hline \multicolumn{5}{|c|}{ Czech Republic } \\
\hline$n=12$ & \multicolumn{4}{|c|}{$\begin{array}{l}\text { Regression statistics: } \mathrm{R}=0.9957 ; \mathrm{R}^{2}=0.9913 \text {; Adjusted } \mathrm{R}^{2}=0.9894 ; \\
\mathrm{F}(2,9)=514.1645 ; p<0.0000 ; \text { Standard error of estimate: } 5128.1105\end{array}$} \\
\hline Constant & $-92,603.1427$ & $27,849.0549$ & -3.3252 & 0.0089 \\
\hline Variable $X_{2}$ & 6981.8000 & 412.3855 & 16.9303 & 0.0000 \\
\hline Variable $X_{6}$ & 14.4160 & 3.4004 & & 0.0022 \\
\hline
\end{tabular}


Table 3. Cont.

\begin{tabular}{|c|c|c|c|c|}
\hline Specification & Coefficients $b$ * & Standard Error & t-Statistic & $p$ Value \\
\hline \multicolumn{5}{|c|}{ Estonia } \\
\hline$n=12$ & \multicolumn{4}{|c|}{$\begin{array}{l}\text { Regression statistics: } \mathrm{R}=0.9645 ; \mathrm{R}^{2}=0.9302 ; \text { Adjusted } \mathrm{R}^{2}=0.9147 ; \\
\mathrm{F}(2,9)=59.9926 ; p<0.0000 ; \text { Standard error of estimate: } 4879.0018\end{array}$} \\
\hline Constant & $-57,231.4088$ & $15,924.9289$ & -3.5938 & 0.0058 \\
\hline Variable $\mathrm{X}_{2}$ & 814.9358 & 82.9463 & 9.8249 & 0.0000 \\
\hline Variable $X_{3}$ & 0.0174 & 0.0042 & 4.0991 & 0.0027 \\
\hline \multicolumn{5}{|c|}{ Latvia } \\
\hline$n=12$ & \multicolumn{4}{|c|}{$\begin{array}{l}\text { Regression statistics: } \mathrm{R}=0.9772 ; \mathrm{R}^{2}=0.9550 ; \text { Adjusted } \mathrm{R}^{2}=0.9450 \\
\mathrm{~F}(2,9)=95.4618 ; p<0.0000 ; \text { Standard error of estimate: } 1476.5264\end{array}$} \\
\hline Constant & $-16,834.4092$ & 3787.5002 & -4.4447 & 0.0016 \\
\hline Variable $\mathrm{X}_{2}$ & 786.3323 & 60.8490 & 12.9227 & 0.0000 \\
\hline Variable $X_{3}$ & 0.0080 & 0.0012 & 6.6629 & 0.0001 \\
\hline \multicolumn{5}{|c|}{ Lithuania } \\
\hline$n=12$ & \multicolumn{4}{|c|}{$\begin{array}{l}\text { Regression statistics: } \mathrm{R}=0.9010 ; \mathrm{R}^{2}=0.8119 ; \text { Adjusted } \mathrm{R}^{2}=0.7581 \\
\mathrm{~F}(2,9)=15.1056 ; p<0.0029 ; \text { Standard error of estimate: } 819.2448\end{array}$} \\
\hline Constant & 5087.1074 & 3024.7424 & 0.0814 & 0.1365 \\
\hline Variable $X_{2}$ & 199.0171 & 36.3285 & 6.6564 & 0.0009 \\
\hline Variable $\mathrm{X}_{7}$ & 4.8019 & 1.9733 & 4.5481 & 0.0452 \\
\hline \multicolumn{5}{|c|}{ Hungary } \\
\hline$n=12$ & \multicolumn{4}{|c|}{$\begin{array}{c}\text { Regression statistics: } \mathrm{R}=0.9655 ; \mathrm{R}^{2}=0.9321 \text {; Adjusted } \mathrm{R}^{2}=0.9170 ; \\
\mathrm{F}(2,9)=61.7729 ; p<0.0000 ; \text { Standard error of estimate: } 6502.0393\end{array}$} \\
\hline Constant & $-99,471.0250$ & $35,750.4096$ & -2.7824 & 0.0213 \\
\hline Variable $\mathrm{X}_{2}$ & 4315.3366 & 464.0497 & 9.2993 & 0.0000 \\
\hline Variable $\mathrm{X}_{6}$ & 28.5730 & 5.5059 & 5.1896 & 0.0006 \\
\hline \multicolumn{5}{|c|}{ Poland } \\
\hline$n=12$ & \multicolumn{4}{|c|}{$\begin{array}{l}\text { Regression statistics: } \mathrm{R}=0.9473 ; \mathrm{R}^{2}=0.8974 ; \text { Adjusted } \mathrm{R}^{2}=0.8871 ; \\
\mathrm{F}(1,10)=87.4432 ; p<0.0000 ; \text { Standard error of estimate: } 21460.1831\end{array}$} \\
\hline Constant & $354,895.8062$ & 21476.7984 & 16.5246 & 0.0000 \\
\hline Variable $X_{2}$ & 3291.2734 & 351.9661 & 9.3511 & 0.0000 \\
\hline \multicolumn{5}{|c|}{ Romania } \\
\hline$n=12$ & \multicolumn{4}{|c|}{$\begin{array}{l}\text { Regression statistics: } \mathrm{R}=0.9157 ; \mathrm{R}^{2}=0.8386 ; \text { Adjusted } \mathrm{R}^{2}=0.8027 \\
\mathrm{~F}(2,9)=23.3733 ; p<0.0003 ; \text { Standard error of estimate: } 5366.7589\end{array}$} \\
\hline Constant & $150,011.9550$ & 4161.9298 & 36.0438 & 0.0000 \\
\hline Variable $\mathrm{X}_{6}$ & 33.3103 & 8.5780 & 3.8832 & 0.0037 \\
\hline Variable $X_{7}$ & -16.3537 & 6.4589 & -2.5319 & 0.0321 \\
\hline \multicolumn{5}{|c|}{ Slovenia } \\
\hline$n=12$ & \multicolumn{4}{|c|}{$\begin{array}{l}\text { Regression statistics: } R=0.9965 ; R^{2}=0.9931 ; \text { Adjusted } R^{2}=0.9915 ; \\
F(2,9)=643.4267 ; p<0.0000 ; \text { Standard error of estimate: } 1904.6089\end{array}$} \\
\hline Constant & $-86,751.0425$ & 9155.9121 & -9.4749 & 0.0000 \\
\hline Variable $X_{2}$ & 1429.5558 & 42.5734 & 33.5786 & 0.0000 \\
\hline Variable $\mathrm{X}_{6}$ & 62.0569 & 3.4366 & 18.0575 & 0.0000 \\
\hline \multicolumn{5}{|c|}{ Slovakia } \\
\hline$n=12$ & \multicolumn{4}{|c|}{$\begin{array}{l}\text { Regression statistics: } \mathrm{R}=0.7947 ; \mathrm{R}^{2}=0.6315 ; \text { Adjusted } \mathrm{R}^{2}=0.5946 ; \\
\mathrm{F}(1,10)=17.1354 ; p<0.0020 ; \text { Standard error of estimate: } 7261.6389\end{array}$} \\
\hline Constant & $121,977.0277$ & 8932.8033 & 13.6550 & 0.0000 \\
\hline Variable $\mathrm{X}_{2}$ & 386.6233 & 93.3987 & 4.1395 & 0.0020 \\
\hline
\end{tabular}


The results of the regression analysis indicated that in the analyzed area of the tourism sector (Accommodation and food service activities), the following factors had a statistically significant impact on the level of GHGs emitted there: $X_{2}$ (air emission intensity for GHGs per unit of output), X3 (number of arrivals at tourist accommodation establishments), $X_{6}$ (turnover value in tourism sector), $X_{7}$ (international tourism receipts). Of these, the most important were: $X_{2}$, which played such a role in 9 out of 10 countries, and $X_{6}$ in five countries. However, it is worth noting that the other less important determinants $\left(X_{3}\right.$ number of arrivals; $X_{7}$-international tourism receipts) are de facto variables describing the economic situation of enterprises on the market just like the variable $\mathrm{X}_{6}$-turnover of enterprises. In conclusion, the impact of the tourism sector on the environment, i.e., the level of GHGs emitted into the air by the accommodation and tourism activities in the CEE countries, was determined by the air emission intensity, i.e., the ecological effectiveness of production, and by the level of turnover in the sector.

The results from Table 3 allowed us to construct a multiple regression equation for each country. Having data for each of the countries concerning the values of the independent variables in 2020 (air emission intensity, number of arrivals, turnover value, international tourism receipts), on the basis of these regression equations it was possible to estimate the level of GHGs emitted by the tourism sector in 2020, i.e., during the pandemic period. The results of these estimates for 2020 are presented in Table 4, where they are additionally contrasted with historical data about the emissions in 2019.

Table 4. Greenhouse gas emission levels in 2019 and 2020 in Central and Eastern European countries.

\begin{tabular}{ccc}
\hline Country & $\mathbf{2 0 1 9}$ & $\mathbf{2 0 2 0}$ \\
\hline Bulgaria & $87,349.4$ & $58,369.0$ \\
Czech Republic & $78,845.0$ & $49,043.0$ \\
Estonia & $16,243.7$ & 3494.3 \\
Latvia & $14,489.4$ & 8703.1 \\
Lithuania & $14,726.3$ & 5179.1 \\
Hungary & $13,5755.6$ & $89,021.9$ \\
Poland & $463,934.7$ & $304,021.6$ \\
Romania & $187,682.8$ & $92,146.3$ \\
Slovenia & $139,461.8$ & $99,124.4$ \\
Slovakia & $144,997.7$ & $142,722.1$ \\
\hline
\end{tabular}

Source: Eurostat data; own calculations.

The results shown in Table 4 indicate that all CEE countries experienced reduced emissions in 2020 as compared to 2019 . The decreases ranged from $1.6 \%$ to $78.5 \%$, with the smallest ones reported in the countries in the south of the region and the biggest ones in the Baltic countries where the decline in turnovers decreases was the most severe. Thus, it can be concluded that the COVID-19 pandemic led to a decrease in greenhouse gas emissions in the tourism sector. The reason was the slowdown in economic activity in the industry in question.

The above results reveal the consequences of the pandemic in reference to 2019. Thus, they do not take into account the fact that if not for the Covid-19 pandemic in 2020 in the CEE region (as well as in the world economy) the GDP would have grown and the tourism sector would have flourished, with increased turnovers of companies operating there. This has been confirmed by the economic forecasts by many world institutions, including the European Commission [80], which are presented in Section 3. Therefore, using the regression analysis, the authors calculated the relationship between the GDP growth and the turnover value in the tourism sector, as well as the potential turnover of businesses and the level of GHG emissions in 2020, assuming the economic growth in the countries of Central and Eastern Europe at the level projected by the European Commission for that year [80]. The results of these estimates are presented in Table 5. 
Table 5. Results from regression analysis and estimates of turnover value and GHG emissions in 2020 (with GDP growth forecast for 2020 from Autumn 2019).

\begin{tabular}{|c|c|c|c|c|c|c|}
\hline \multirow[b]{2}{*}{ Country } & \multirow[b]{2}{*}{ Coefficient $b$} & \multirow[b]{2}{*}{$p$-Value } & \multicolumn{2}{|c|}{ Turnover } & \multicolumn{2}{|c|}{ Greenhouses Gases } \\
\hline & & & $\begin{array}{c}2020 \\
(m \ln \text { EUR) }\end{array}$ & $\begin{array}{c}2020 / 2019 \\
(\%)\end{array}$ & $\begin{array}{c}2020 \\
(\mathrm{mln} \text { EUR) }\end{array}$ & $\begin{array}{c}2020 / 2019 \\
(\%)\end{array}$ \\
\hline Bulgaria & 0.1339 & 0.0000 & 2848.3 & 7.22 & $87,541.2$ & 7.21 \\
\hline Czech Republic & 0.0714 & 0.0000 & 8232.0 & 3.88 & $79,152.1$ & 3.30 \\
\hline Estonia & 0.1029 & 0.0000 & 1064.7 & 4.42 & $16,288.8$ & 3.97 \\
\hline Latvia & 0.0964 & 0.0000 & 1089.1 & 5.83 & $14,549.4$ & 5.10 \\
\hline Lithuania & 0.0650 & 0.0000 & 1189.6 & 5.41 & $14,787.3$ & 4.32 \\
\hline Hungary & 0.0697 & 0.0000 & 4741.9 & 5.63 & $136,008.4$ & 4.25 \\
\hline Poland & 0.0455 & 0.0000 & $12,614.1$ & 6.31 & $464,683.3$ & 5.13 \\
\hline Romania & 0.0717 & 0.0000 & 6690.5 & 7.31 & $188,138.4$ & 4.92 \\
\hline Slovenia & 0.0989 & 0.0000 & 2375.2 & 5.11 & $139,577.2$ & 5.11 \\
\hline Slovakia & 0.0744 & 0.0000 & 2774.7 & 6.42 & $145,165.0$ & 7.21 \\
\hline
\end{tabular}

Source: own calculations based on data [32-37,37,38,38-60].

The results indicate that the level of GDP statistically significantly affects the turnover of tourist companies ( $p$-value $<0)$. The values of coefficient $b$ indicate that, depending on the country, an increase in gross domestic product at market prices by a million Euros results in an increase in turnover of enterprises categorized as Accommodation and Food Service Activities at the level of 46-134 thousand Euros. Thus, if in 2020 the COVID-19 pandemic had not occurred and there had been economic growth at the level projected by the European Commission [60], then in all CEE countries the turnover of enterprises in this field of tourism activity would have risen in comparison to 2019, amounting to 3.9-7.3\%, depending on the country. Simultaneously, that would translate into increased levels of GHG emissions in tourism by $3.3-7.2 \%$ relative to 2019 .

Then, the authors proceeded to determine the deviation of actual 2020 emission values from the projected ones. For this purpose, they compared the recorded level of GHGs emitted by Accommodation and Food Service Activities in 2020, i.e., at the time of the Covid-19 pandemic (see Table 5), with the projected emissions, i.e., those generated if the economy had grown in 2020. The results of this comparison are shown in Figure 2. In addition, these results are contrasted with changes in emissions relative to 2019.

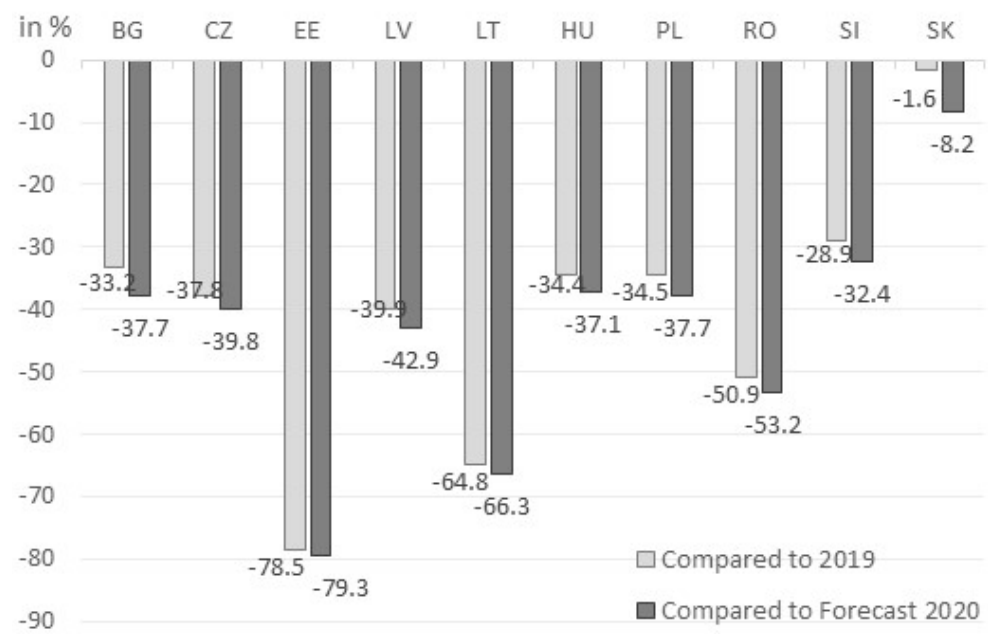

Figure 2. Change in Central and Eastern European countries' GHG emissions in 2020 with real GDP compared to 2019 and to 2020 (with GDP growth in 2020 consistent with European Commission projection). Source: based on Tables 3 and 4.

The results in Figure 2 show that the COVID-19 pandemic caused a decrease in tourism-related GHG emissions in all the CEE countries. These decreases are relative 
both to 2019 and to the estimated level of emissions that would have been achieved if the countries under study had enjoyed economic growth in 2020 as projected by the European Commission. Moreover, the potential impact of COVID-19 was found to be even stronger. Taking the potential projected growth in 2020 as a base point, it was found that, apart from Slovakia with the decrease at $8.2 \%$, the decline in emissions exceeded $32 \%$, reaching as much as $79.3 \%$ in Estonia. The highest reductions in the negative environmental impact were reported in the Baltic States, while the lowest-in the countries in the south of the region, i.e., in Slovakia and Slovenia.

\section{Discussion and Conclusions}

The global COVID-19 pandemic has negatively affected the tourism sector and caused many economic and social losses. Governmental measures to combat the pandemic, such as lockdown of economies, closure of national borders, quarantine, and mandatory testing of travelers have significantly changed the functioning of the sector. The pandemic waves recurring every few months forced the authorities to constantly modify the laws and regulations concerning security measures and sanitary restrictions, which further aggravated the negative economic impact of the pandemic on the tourism sector. As demonstrated in the literature review above $[26,29,81]$, the pandemic similarly harmed every type of tourism activity, including accommodation and food service activities. Admittedly, domestic tourism has been less severely affected, but this does not compensate for the overall losses suffered by the sector in 2020. In the examined region of Central and Eastern Europe, both arrivals at tourist accommodation establishments and international tourism receipts have declined by more than $50 \%$ in the majority of those countries.

However, according to some researchers, COVID-19 was a "Blessing in Disguise" for the environment as it caused economies to pollute less [37]. Of course, not all economic sectors have a negative impact on the environment; some are devastating to the climate and others vice versa. How did it look in tourism sector where the COVID-19 pandemic caused such a dramatic decline in travel and severe economic consequences for the hospitality industry? What were the environmental impacts of the constraints on tourism business at the time of the pandemic? These research questions were looked into in this paper. The authors' review of the literature confirms that there are few publications that directly address the issue of the environmental impact of tourism, and there are none investigating the impact of COVID-19. Moreover, when preparing this review, the authors found that researchers suggest that this impact can be positive as well as negative, thus failing to provide a clear answer to the question of the nature of tourism's effect on the natural environment.

The purpose of this paper is to investigate what was the effect of the Covid-19 pandemic on the impact that tourism sector, namely the accommodation and related food service activities, had on the level of GHGs emissions. The study area was the region of Central and Eastern Europe that has not suffered as many negative health and economic impacts as Western European countries during the first wave of the Covid-19 pandemic. The study covered 10 EU countries in the region: Bulgaria, the Czech Republic, Estonia, Latvia, Lithuania, Hungary, Poland, Romania, Slovenia and Slovakia. The results of the research provided some basic conclusions. There has been a positive correlation between the level of tourism sector development and the level of GHG emissions generated by this sector. The conducted research indicated that as a result of a sharp decrease in arrivals and in business turnover, there GHG emissions in all CEE countries have fallen as compared to 2019. This impact is even greater when we take into consideration the potential economic growth that did not occur in these countries due to the pandemic. Hence, the COVID-19 pandemic resulted in favorable trends in the environmental impact of the tourism sector in CEE countries. This study also confirms the findings of other researchers [61,62] that the relationship between tourism sector growth and the state of the natural environment is negative, which is in contrast to the conclusions drawn by Tian et al., [16]. Following Gössling et al., [15] it was also concluded that the impact of tourism on the environment depends on the country of tourist destination. The results of the study have shown that 
during the pandemic in the Central and Eastern European region, the highest reductions in negative environmental impacts have taken place in the Baltic countries, whereas the countries in the southern part of region, i.e., Slovakia and Slovenia suffered the least. The third important finding of the present study is that in the long run the most important driver of GHG emissions in the tourism accommodation industry in the investigated EU region is air emission intensity, which is consistent with the study results by Robaina-Alves et al., [22] Thus, what eliminated the negative impact on the environment in the long perspective was the effectiveness of production, i.e., environmentally friendly investments. By providing these findings, the authors have filled a research gap that existed in the literature.

A question arises whether this beneficial effect on the environment is only temporary and how it will change once the pandemic ends. It is to be hoped that this effect will sustain at least in part. As pointed out by Fletcher et al., [82], the current restrictions, limitations and control of mobility have shown that it is possible to regulate tourist flows according to its purpose. There are therefore grounds for believing that governments will choose to have a regulatory impact on the tourism sector so that the beneficial changes that have occurred in the environment can remain for longer.

The study presented in this paper also has several shortcomings and hence some research limitations. The number of observations is only 12 years. The use of panel data would increase the dataset and could allow for the identification of unobservable individual effects (with single countries). Hence, it seems that it would be worthwhile to continue this research in 2021 and beyond to extend this research with further threads. Besides, there is also scope for expanding the research to countries in other regions of Europe, instead of limiting it only to Central and Eastern Europe. There is also a "lesson" that can be incorporated in future development strategies, i.e., the concept of sustainable tourism to be implemented, the idea of slow tourism to be promoted as well as the natural environment to be taken care of.

Author Contributions: Conceptualization, R.N. and B.Ž.; methodology, R.N.; software, R.N.; validation, R.N. and B.Ž.; formal analysis, R.N. and B.Ž.; investigation, R.N. and B.Ž.; resources, B.Ž.; data curation, R.N. and B.Ž.; writing—original draft preparation, R.N. and B.Ž.; writing-review and editing, R.N. and B.Ž.; visualization, R.N. and B.Ž.; supervision, R.N. and B.Ž.; project administration, R.N. and B.Ž.; funding acquisition, R.N. and B.Ž. All authors have read and agreed to the published version of the manuscript.

Funding: The project is co-financed within the framework of the program of the Minister of Science and Higher Education under the name "Regional Excellence Initiative" in the years 2019-2022; project number 001/RID/2018/19; the amount of financing PLN 10,684,000.00.

Institutional Review Board Statement: Not applicable.

Informed Consent Statement: Not applicable.

Data Availability Statement: Not applicable. The study uses publicly available data from Eurostat, OECD and UNWTO, links to which are provided in the references.

Conflicts of Interest: The authors declare no conflict of interest.

\section{References}

1. Jiang, P.; Klemeš, J.J.; Fan, Y.V.; Fu, X.; Bee, Y.M. More is not enough: A deeper understanding of the COVID-19 impacts on healthcare, energy and environment is crucial. Int. J. Environ. Res. Public Health 2021, 18, 684. [CrossRef]

2. Gregurec, I.; Tomičić Furjan, M.; Tomičić-Pupek, K. The impact of COVID-19 on sustainable business models in SMEs. Sustainability 2021, 13, 1098. [CrossRef]

3. Zhang, D.; Hao, M.; Morse, S. Is environmental sustainability taking a backseat in China after COVID-19? The perspective of business managers. Sustainability 2020, 12, 10369. [CrossRef]

4. Sadeh, A.; Radu, C.F.; Feniser, C.; Borşa, A. Governmental intervention and its impact on growth, economic development, and technology in OECD countries. Sustainability 2021, 13, 166. [CrossRef]

5. Çetin, C.; Kara, A. Global Surveillance, Travel, and Trade during a Pandemic. Turk. J. Med. Sci. 2020, 50, 527-533. Available online: https://dergipark.org.tr/en/pub/tbtkmedical/issue/53865/724510 (accessed on 13 January 2021). [CrossRef] [PubMed] 
6. IEA. World Energy Outlook 2019; IEA: Paris, France, 2019; Available online: :https://www.iea.org/reports/world-energy-outlook -2020 (accessed on 24 January 2021).

7. Nagaj, R.; Korpysa, J. Impact of COVID-19 on the level of energy poverty in Poland. Energies 2020, 13, 4977. [CrossRef]

8. Chevallier, J. COVID-19 outbreak and $\mathrm{CO}_{2}$ emissions: Macro-financial linkages. J. Risk Financ. Manag. 2021, 14, 12. [CrossRef]

9. Uğur, N.G.; Akbıyık, A. Impacts of COVID-19 on global tourism industry: A cross-regional comparison. Tour. Manag. Perspect. 2020, 36, 100744. [CrossRef] [PubMed]

10. Gursoy, D.; Chi, C.G. Effects of COVID-19 pandemic on hospitality industry: Review of the current situations and a research agenda. J. Hosp. Mark. Manag. 2020, 29, 527-529. [CrossRef]

11. European Energy Network. Position Paper on Energy Poverty in the European Union. In Italian Agency for New Technologies, Energy and Sustainable Economic Development (ENEA); Energy Efficiency Department Roma: Roma, Italy, 2019; Available online: http:/ / enr-network.org/wp-content/uploads/ENERGYPOVERTY-EnRPositionPaper-Energypoverty-Jan-2019.pdf (accessed on 24 January 2021).

12. UNDP. Annual Report 2019: United Nations Development Programme; UNDP: New York, NY, USA, 2020; Available online: https: / / annualreport.undp.org/assets/UNDP-Annual-Report-2019-en.pdf (accessed on 6 January 2021).

13. Dogaru, L. Green economy and green growth-Opportunities for sustainable development. Proceedings 2020, 63, 70. [CrossRef]

14. Russo, M.A.; Relvas, H.; Gama, C.; Lopes, M.; Borrego, C.; Rodrigues, V.; Robaina, M.; Madaleno, M.; Carneiro, M.J.; Eusebio, C.; et al. Estimating emissions from tourism activities. Atmos. Environ. 2020, 220, 117048. [CrossRef]

15. Gössling, S.; Peeters, P.; Ceron, J.-P.; Dubois, G.; Patterson, T.; Richardson, R.B. The eco-efficiency of tourism. Ecol. Econ. 2005, 54, 417-434. [CrossRef]

16. Tian, X.-L.; Bélaïd, F.; Ahmad, N. Exploring the nexus between tourism development and environmental quality: Role of Renewable energy consumption and Income. Struct. Chang. Econ. Dyn. 2021, 56, 53-63. [CrossRef]

17. Basarir, C.; Cakir, Y.N. Causal interactions between $\mathrm{CO}_{2}$ emissions, financial development, energy and tourism. Asian Econ. Financ. Rev. 2015, 5, 1227-1238. [CrossRef]

18. Neger, C.; Prettenthaler, F.; Gossling, S.; Damm, A. Carbon intensity of tourism in Austria: Estimates and policy implications. J. Outdoor Recreat. Tour. 2021, 33, 100331. [CrossRef]

19. Robaina, M.; Madaleno, M.; Silva, S.; Eusébio, C.; Carneiro, M.J.; Gama, C.; Oliveira, K.; Russo, M.A.; Monteiro, A. The relationship between tourism and air quality in five European countries. Econ. Anal. Policy 2020, 67, 261-272. [CrossRef]

20. Dogan, E.; Aslan, A. Exploring the relationship among $\mathrm{CO}_{2}$ emissions, real GDP, energy consumption and tourism in the EU and candidate countries: Evidence from panel models robust to heterogeneity and cross-sectional dependence. Renew. Sustain. Energy Rev. 2017, 77, 239-245. [CrossRef]

21. Tang, C.; Zhong, L.; Ng, P. Factors that influence the tourism industry's carbon emissions: A tourism area life cycle model perspective. Energy Policy 2017, 109, 704-718. [CrossRef]

22. Robaina-Alves, M.; Moutinho, V.; Costa, R. Change in energy-related $\mathrm{CO}_{2}$ (carbon dioxide) emissions in Portuguese tourism: $\mathrm{A}$ decomposition analysis from 2000 to 2008. J. Clean. Prod. 2016, 111, 520-528. [CrossRef]

23. Katircioglu, S.T.; Feridun, M.; Kilinc, C. Estimating tourism-induced energy consumption and $\mathrm{CO}_{2}$ emissions: The case of $\mathrm{Cyprus.}$ Renew. Sustain. Energy Rev. 2014, 29, 634-640. [CrossRef]

24. Alonso, A.D.; Kok, S.K.; Bressan, A.; O’Shea, M.; Sakellarios, N.; Koresis, A.; Buitrago Solis, M.A.; Santoni, L.J. COVID-19, aftermath, impacts, and hospitality firms: An international perspective. Int. J. Hosp. Manag. 2020, 91, 102654. [CrossRef]

25. Bakar, N.A.; Rosbi, S. Effect of Coronavirus disease (COVID-19) to tourism industry. Int. J. Adv. Eng. Res. Sci. 2020, 7, 189-193. [CrossRef]

26. Baum, T.; Hai, N.T.T. Hospitality, tourism, human rights and the impact of COVID-19. Int. J. Contemp. Hosp. Manag. 2020, 32, 2397-2407. [CrossRef]

27. Nicola, M.; Alsafi, Z.; Sohrabi, C.; Kerwan, A.; Al-Jabir, A.; Iosifidis, C.; Agha, M.; Agha, R. The socio-economic implications of the coronavirus and COVID-19 pandemic: A review. Int. J. Surg. 2020, 78, 185-193. [CrossRef] [PubMed]

28. Zielinski, S.; Botero, C.M. Beach tourism in times of COVID-19 pandemic: Critical issues, knowledge gaps and research opportunities. Int. J. Environ. Res. Public Health 2020, 17, 7288. [CrossRef] [PubMed]

29. Gössling, S.; Scott, D.; Hall, M.C. Pandemics, tourism and global change: A rapid assessment of COVID-19. J. Sustain. Tour. 2021, 29, 1-20. [CrossRef]

30. UNWTO. UNWTO World Tourism Barometer and Statistical Annex. UNWTO World Tour. Barom. 2021, 19. Available online: https:/ / www.e-unwto.org/doi/epdf/10.18111/wtobarometereng.2021.19.1.1 (accessed on 1 February 2021).

31. Eggers, F. Masters of disasters? Challenges and opportunities for SMEs in times of crisis. J. Bus. Res. 2020, 116, 199-208. [CrossRef]

32. Eurostat. Available online: https://ec.europa.eu/eurostat/statistics-explained/index.php/Tourism_statistics (accessed on 27 December 2020).

33. OECD. Stat. Available online: https://stats.oecd.org/Index.aspx?DataSetCode=TOURISM_DOMESTIC\# (accessed on 27 December 2020).

34. UNWTO. UNWTO World Tourism Barometer and Statistical Annex. UNWTO World Tour. Barom. 2020, 18, 1-36. [CrossRef]

35. Gallego, I.; Font, X. Changes in air passenger demand as a result of the COVID-19 crisis: Using Big Data to inform tourism policy. J. Sustain. Tour. 2020, 1-20. [CrossRef]

36. Williams, A.M.; Balaz, V. Tourism risk and uncertainty: Theoretical reflections. J. Travel Res. 2015, 54, 271-287. [CrossRef] 
37. Muhammad, S.; Long, X.; Salman, M. COVID-19 pandemic and environmental pollution: A blessing in disguise? Sci. Total Environ. 2020, 728, 138820. [CrossRef]

38. Nagaj, R.; Žuromskaitè, B. A Scientific Experiment as a Research Method in the Tourism Sector in the Context of Increased Terrorism Risks. In Problems, Methods and Tools in Experimental and Behavioral Economics. CMEE 2017. Springer Proceedings in Business and Economics; Nermend, K., Łatuszyńska, M., Eds.; Springer: Cham, Switzerland, 2018; pp. 313-330. [CrossRef]

39. Canh, N.P.; Thanh, S.D. Domestic tourism spending and economic vulnerability. Ann. Tour. Res. 2020, 85, 103063. [CrossRef]

40. Steffen, R.; Lautenschlager, S.; Fehr, J. Travel restrictions and lockdown during the COVID-19 pandemic-impact on notified infectious diseases in Switzerland. J. Travel Med. 2020, 27. [CrossRef] [PubMed]

41. Nagaj, R.; Žuromskaitè, B. CEE Millennial travellers' attitude towards security measures applied in tourism infrastructure. Tour. Int. Interdiscip. J. 2021, 69, 140-155. [CrossRef]

42. Nagaj, R.; Žuromskaitė, B. Security measures as a factor in the competitiveness of accommodation facilities. J. Risk Financ. Manag. 2020, 13, 99. [CrossRef]

43. Assaf, A.; Scuderi, R. COVID-19 and the recovery of the tourism industry. Tour. Econ. 2020, 26, 731-733. [CrossRef]

44. Altuntas, F.; Gok, M.S. The effect of COVID-19 pandemic on domestic tourism: A DEMATEL method analysis on quarantine decisions. Int. J. Hosp. Manag. 2021, 92, 102719. [CrossRef]

45. Leitão, N.C.; Lorente, D.B. The linkage between economic growth, renewable energy, tourism, $\mathrm{CO}_{2}$ emissions, and international trade: The evidence for the european union. Energies 2020, 13, 4838. [CrossRef]

46. Sun, Y.-Y. Decomposition of tourism greenhouse gas emissions: Revealing the dynamics between tourism economic growth, technological efficiency, and carbon emissions. Tour. Manag. 2016, 55, 326-336. [CrossRef]

47. Gössling, S.; Lund-Durlacher, D. Tourist accommodation, climate change and mitigation: An assessment for Austria. J. Outdoor Recreat. Tour. 2021, 100367. [CrossRef]

48. Koçak, E.; Rulucak, R.; Ulucak, Z.Ş. The impact of tourism developments on $\mathrm{CO}_{2}$ emissions: An advanced panel data estimation. Tour. Manag. Perspect. 2020, 33, 100611. [CrossRef]

49. Li, L.; Li, J.; Tang, L.; Wang, S. Balancing tourism's economic benefit and $\mathrm{CO}_{2}$ emissions: An insight from input-output and tourism satellite account analysis. Sustainability 2019, 11, 1052. [CrossRef]

50. Tsai, K.-T.; Lin, T.-P.; Hwang, R.-L.; Huang, Y.-J. Carbon dioxide emissions generated by energy consumption of hotels and homestay facilities in Taiwan. Tour. Manag. 2014, 42, 13-21. [CrossRef]

51. Xuchao, W.; Priyadarsini, R.; Eang, L.S. Benchmarking energy use and greenhouse gas emissions in Singapore's hotel industry. Energy Policy 2010, 38, 4520-4527. [CrossRef]

52. Abeydeera, L.H.U.W.; Karunasena, G. Carbon emissions of hotels: The case of the sri lankan hotel industry. Buildings 2019, 9, 227. [CrossRef]

53. Deng, S.M.; Burnett, J. A study of energy performance of hotel buildings in Hong Kong. Energy Build. 2000, 31, 7-12. [CrossRef]

54. Tang, M.; Fu, X.; Cao, H.; Shen, Y.; Deng, H.; Wu, G. Energy performance of hotel buildings in Lijiang, China. Sustainability 2016, 8, 780. [CrossRef]

55. Taylor, S.; Peacock, A.; Banfill, P.; Shao, L. Reduction of greenhouse gas emissions from UK hotels in 2030. Build. Environ. 2010, 45, 1389-1400. [CrossRef]

56. Huang, K.-T.; Wangb, J.C.; Wang, Y.-C. Analysis and benchmarking of greenhouse gas emissions of luxuryhotels. Int. J. Hosp. Manag. 2015, 51, 56-66. [CrossRef]

57. Filimonau, V.; Dickinson, J.; Robbins, D.; Huijbregts, D.A.J. Reviewing the carbon footprint analysis of hotels: Life Cycle Energy Analysis (LCEA) as a holistic method for carbon impact appraisal of tourist accommodation. J. Clean. Prod. 2011, 19, 1917-1930. [CrossRef]

58. Greenview. Cornell Hotel Sustainability Benchmarking Index. Available online: https://greenview.sg/chsb-2020/ (accessed on 17 March 2021).

59. Chen, L.; Thapa, B.; Yan, W. The relationship between tourism, carbon dioxide emissions, and economic growth in the Yangtze River Delta, China. Sustainability 2018, 10, 2118. [CrossRef]

60. International Tourism Partnership. Hotel Global Decarbonisation Report: Aligning the Sector with the Paris Climate Agreement Towards 2030 and 2050; International Tourism Partnership: London, UK, 2017; Available online: https:/ / buildingtransparency-live-87c7ea 3ad4714-809eeaa.divio-media.com/filer_public/c4/9c/c49c0756-d91b-43b6-9819-6f4a2215052b/wc_am-hoteldecarbonizatio nreportpdf.pdf (accessed on 17 March 2021).

61. Lee, J.W.; Brahmasrene, T. Investigating the influence of tourism on economic growth and carbon emissions: Evidence from panel analysis of the European Union. Tour. Manag. 2013, 38, 69-76. [CrossRef]

62. Katircioglu, S.T. Testing the tourism-induced EKC hypothesis: The case of Singapore. Econ. Model. 2014, 41, 383-391. [CrossRef]

63. Paramati, S.R.; Shahbaz, M.; Alam, M.S. Does tourism degrade environmental quality? A comparative study of Eastern and Western European Union. Transp. Res. Part D Transp. Environ. 2017, 50, 1-13. [CrossRef]

64. Paramati, S.R.; Alam, M.S.; Chen, C.F. The effects of tourism on economic growth and $\mathrm{CO}_{2}$ emissions: A comparison between developed and developing economies. J. Travel Res. 2017, 56, 712-724. [CrossRef]

65. Chu, W.; Calise, F.; Duić, N.; Østergaard, P.A.; Vicidomini, M.; Wang, Q. Recent advances in technology, strategy and application of sustainable energy systems. Energies 2020, 13, 5229. [CrossRef] 
66. Mahato, S.; Ghosh, K.G. Short-term exposure to ambient air quality of the most polluted Indian cities due to lockdown amid SARS-CoV-2. Environ. Res. 2020, 188, 109835. [CrossRef]

67. Huang, X.; Ding, A.; Gao, J.; Zheng, B.; Zhou, D.; Qi, X.; Tang, R.; Ren, C.; Nie, W.; Chi, X.; et al. Enhanced secondary pollution offset reduction of primary emissions during COVID-19 lockdown in China. Natl. Sci. Rev. 2020, 8, 1-9. [CrossRef]

68. Nakada, L.Y.K.; Urban, R.C. COVID-19 pandemic: Impacts on the air quality during the partial lockdown in Sao Paulo state, Brazil. Sci. Total Environ. 2020, 730, 139087. [CrossRef] [PubMed]

69. Selvam, S.; Muthukumar, P.; Venkatramanan, S.; Roy, P.D.; Manikanda Bharath, K.; Jesuraja, K. SARS-CoV-2 pandemic lockdown: Effects on air quality in the industrialized Gujarat state of India. Sci. Total Environ. 2020, 737, 140391. [CrossRef]

70. Ordóñez, C.; Garrido-Perez, J.M.; García-Herrera, R. Early spring near-surface ozone in Europe during the COVID-19 shutdown: Meteorological effects outweigh emission changes. Sci. Total Environ. 2020, 747, 141322. [CrossRef]

71. Collivignarelli, M.C.; Abbà, A.; Bertanza, G.; Pedrazzani, R.; Ricciardi, P.; Miino, M.C. Lockdown for CoViD-2019 in Milan: What are the effects on air quality? Sci. Total Environ. 2020, 732, 139280. [CrossRef]

72. Bertocchi, D.; Camatti, N.; Giove, S.; van der Borg, J. Venice and overtourism: Simulating sustainable development scenarios through a tourism carrying capacity model. Sustainability 2020, 12, 512. [CrossRef]

73. Depellegrin, D.; Bastianini, M.; Fadini, A.; Menegon, S. The effects of COVID-19 induced lockdown measures on maritime settings of a coastal region. Sci. Total Environ. 2020, 740, 140123. [CrossRef]

74. Braga, F.; Scarpa, G.M.; Brando, V.E.; Manfè, G.; Zaggia, L. COVID-19 lockdown measures reveal human impact on water transparency in the Venice Lagoon. Sci. Total Environ. 2020, 736, 139612. [CrossRef]

75. Bashir, M.F.; Ma, B.; Komal, B.; Bashir, M.A.; Tan, D.; Bashir, M. Correlation between climate indicators and COVID-19 pandemic in New York, USA. Sci. Total Environ. 2020, 728, 138835. [CrossRef] [PubMed]

76. Zangari, S.; Hill, D.T.; Charette, A.T.; Mirowsky, J.E. Air quality changes in New York City during the COVID-19 pandemic. Sci. Total Environ. 2020, 742, 140496. [CrossRef] [PubMed]

77. Lokhandwala, S.; Gautam, P. Indirect impact of COVID-19 on environment: A brief study in Indian context. Environ. Res. 2020, 188, 109807. [CrossRef] [PubMed]

78. Huh, T. Comparative and relational trajectory of economic growth and greenhouse gas emission: Coupled or decoupled? Energies 2020, 13, 2550. [CrossRef]

79. Arango Miranda, R.; Hausler, R.; Romero Lopez, R.; Glaus, M.; Pasillas-Diaz, J.R. Testing the environmental kuznets curve hypothesis in North America's Free Trade Agreement (NAFTA) countries. Energies 2020, 13, 3104. [CrossRef]

80. European Commission. European Economic Forecast Autumn 2019. Institutional Paper 115; Publications Office of the European Union: Luxembourg, 2019; Available online: https://ec.europa.eu/info/sites/info/files/economy-finance/ip115_en_0.pdf (accessed on 13 January 2021).

81. Hall, C.M.; Scott, D.; Gössling, S. Pandemics, transformations and tourism: Be careful what you wish for. Tour. Geogr. 2020, 22, 577-598. [CrossRef]

82. Fletcher, R.; Murray Mas, I.; Bl_azquez-Salom, M.; Blanco-Romero, A. Tourism, Degrowth, and the COVID-19 Crisis. Political Ecology Network. 24 March 2020. Available online: https:/ / politicalecologynetwork.org/2020/03/24/tourism-degrowth-and-thecovid-19-crisis / (accessed on 24 January 2021). 